\title{
TroyAcademy
}

International Journal of Social Sciences

\section{Kurumsal Liderlik: Nereden Nereye?}

\author{
Araştırma Makalesi/Research Article
}

\section{Talha Sait ATAY* Oktay KOÇ**}

\section{ÖZET}

Kurumsal liderlik, Selznick tarafindan geliştirilmiş ve fakat 1950'lerde donup kalmış gibi çok fazla incelemeye tabi tutulmamıştır. Dolayısıyla örgütlerde geleneksel liderlik fonksiyonları yanında, değer yaratma ve bunları örgüte aşılama ile etkisini gösteren bu tip liderliği yeniden ele alma zarureti hasıl olmuştur. Mevcut çalışma literatür taraması yoluyla kurumsal liderliğin geçmişten bugüne ve hatta geleceğe uzanan öyküsünü araştırmaktadır. Bu anlamda kamu değeri kavramının giderek daha fazla önem kazandığı bir dönemde, bu tip bir liderliğin örgütler için fark yaratabilecek bir model olabileceği neticesine varılmıştır.

Anahtar Kelimeler: Selznick, Kurumsal Liderlik, Değer, Kamu Değeri, Kurumsallaşma

\section{Institutional Leadership: From Where? To Where?}

\begin{abstract}
Institutional leadership was developed by Selznick, but has not been subjected to much scrutiny as it was frozen in the 1950s. Therefore, there has been an obligation to reconsider this type of leadership, which shows its effect by creating value and infusing them into the organization, in addition to traditional leadership functions in organizations. Current study explores the story of institutional leadership from the past to the present and even into the future, through a literature review. In this sense, at a time when the concept of public value gains more and more importance, it has been concluded that this type of leadership can be a model that might create a difference for organizations.
\end{abstract}

Keywords: Selznick, Institutional Leadership, Value, Public Value, Institutionalism

* Doktora Öğrencisi, Kocaeli Üniversitesi, Siyaset Bilimi ve Kamu Yönetimi Anabilim Dalı, talhasaitatay@gmail.com, ORCID ID: https://orcid.org/0000-0002-3778-2072

** Prof. Dr., Sinop Üniversitesi, Yönetim Bilimleri Anabilim Dalı, oktaykoc@sinop.edu.tr, ORCID ID: https://orcid.org/0000-0002-0612-6929 


\section{GíRiş}

Geçmişten günümüze liderlik alanında yapılan çalışmalara bakıldığında bazı liderlik yaklaşımlarının büyük ilgi uyandırdıkları (Örn: Burns, 1978; Bass, 1985 vb.) bazılarının ise yeterince ilgi uyandırmadıkları (Örn: Stogdill, 1948) görülmektedir. Kurumsal liderlik gibi, örgütsel bağlamda oldukça dikkate değer olan ve etkileri itibariyle belki diğerlerine nazaran daha güçlü bir alana sahip olabilecek bir yaklaşımın, bunlardan ikincisine daha yakın durduğu, literatür araştırmasına bakıldığında kolaylıkla ileri sürülebilir. Kurumsal liderliğin araştırmacılarca çok daha üzerinde durulmamasının, dönemsel ve kuramsal etkileri olduğu da ifade edilebilir. Özellikle ikinci dünya savaşı sonrası denilebilecek bir dönemde ileri sürülmesi ile birlikte, liderlikte davranışsal ve durumsal yaklaşımların daha fazlalıkla ele alınması, kurumsal liderliğin değerlere odaklı niteliğinin (Selznick, 1957) gözden kaçırılmasına neden olmuştur denilebilir.

Doğrusu nitelikleri, yaklaşımları veya etiketleri ne olursa olsun liderler, yönetimi başlatma ve biçimlendirme yetkisine dayalı sorumluluklarından dolayı örgütlerde kilit aktörler olarak işlev görürler (Askeland, 2020: 142). Bu kişilerin düşünme ve hareket etme biçimleri, çalıştıkları alan ve kurumlar tarafından sınırlandırılsa da; yeni hedefleri yansıtan, farklı ve hatta çatışan değerleri içselleştiren yapılar inşa etmek için ve yine bunlardan bazılarını kurumsallaştırmak adına mücadele ettikleri söylenebilir (Struminska-Kutra ve Askeland, 2020: 119). Doğrusu kurumsallaşmanın, örgütlerin etkinliğini ve dayanıklılığını artırdı̆̆ı konusunda bir fikir birliği de mevcuttur (Boin ve Christensen, 2008: 5). Hatta her örgütün, gelişim düzeyiyle de bağlantılı olarak zaman içerisinde kurumsal nitelikler kazandığı rahatlıkla ileri sürülebilir. Bu süreç esnasında bir liderin rolü, en başta teknik zorunlulukları gidermenin yanında henüz var olmayan örgütsel değerleri oluşturmanın zorluğuna katlanmasıdır, denilebilir (Besharov ve Khurana, 2015: 63).

Esasen iki farklı kurumsal kuramın eski ve yeni olarak tasnif edildiği bir izlekte (bkz: Selznick, 1996), adı ne olursa olsun, bir "örgütün” (organization) bir "kurum” (institution) olarak doğmadığ 1 açıkça söylenebilir. Kurumsal özellikler yıllar geçtikçe kazanılır ve geniş çapta kabul görmesi ve itirazsız kabul edilmesi ancak bu süreçte olur (Boin ve Christensen, 2008: 4-5). Elbette yeni kurumsalcılığın pasif aktör/aktif eyleyen (veya kurumsal girişimci) ikilemesi karşısında (DiMaggio, 1988), eski kurumsalcılığın aktif eyleyen olarak liderleri tanımlıyor olması (Selznick, 1957; Washington vd., 2008), bir yerinde kurumsallaşmayı sağlamak üzere bilinçli ve maksatlı bir şekilde hareket eden bir aktöre işaret ettiği anlamına da gelir. Doğrusu sosyal dünyanın (süregelen kurallardaki, uygulamalardaki ve eylemlerdeki koşulları belirleyen yapılarla) önemli ölçüde kurumlardan oluştuğu (Lawrance ve Shadnam, 2008: 2288-2289) göz önüne alındığında, eski kurumsalcılığın tanımladığ1 aktif, maksatlı ve bilinçli aktör olarak liderlerin (Selznick, 1957), kurumların yaratılması ve 
kurumsallaşma bakımından sahip olduğu önem ve işlev çok daha iyi anlaşıllabilecek ve aslında böylece yeni kurumsalcılıktan ayrıldığı en önemli nokta olacaktır (bkz: Selznick, 1996). Kendi tarihlerinin varlıkları olarak kurumlar (Shinn, 1996: 36) ve bunlardaki değişim (Battilana vd., 2009) bir süreç şeklinde ele alınacak olursa, bağlamın yanı sıra bir örgüt içindeki diğer politik aktörlerin eylem ve faaliyetlerinden güçlü bir şekilde etkilenen süreçler aracılığıyla böylesi bir değişimin gerçekleşebileceği ifade edilebilir (Kraatz ve Moore, 2002: 125). Ancak ilginç bir şekilde bugüne kadar örgüt araştırmaları kapsamında kurumsal liderliğin genellikle gözden kaçırılan bir tasarım olduğu özellikle vurgulanmalıdır (Silva, 2020: 81). Oysa çeşitli yazarlara da atıf yaparak Scott (2003), liderliğin biçimsel yapıyla bütünleşmek yoluyla tertip edildiğini ve rutinleştiğini ileri sürmektedir. Selznick (1957) bu hususu hemen hemen kurumsallaşma ile karşılamakta ve kurumsallaşmanın da yap1 ve faaliyetlerin teknik gereklilikler ötesinde değer aşılanmış hale gelmesini sağlayan bir süreci gerektirdiğini ileri sürmektedir. Ve hatta biraz daha ileri giderek Selznick (1996: 271), liderliğin temel bir sorumluluğunun, -fayda ve maliyetleri bakımından- kurumsallaşma sürecini izlemek olduğunu ileri sürmektedir.

Bütün bunlara dayanarak esas itibariyle Philip Selznick (1957) tarafından kavramsallaştırılmış, örgütün evrimsel süreçlerinde kritik bir rol oynayan ve tarihsel olarak bakıldığında hak ettiği değeri bulamamış olan "kurumsal liderlik" modeline, özellikle yeni süreçte ortaya çıkan kamu değeri, para için değer, değer odaklı yönetim gibi kavramlar da göz önünde bulundurularak odaklanmanın önemli olabileceği öne sürülebilir. Bunun nedeni, bu tip liderlerin, Selznick’in ifadesiyle teknik gereksinimlerinin ötesinde örgütlerine “değer aşılayarak” kurumsallaşma sürecine önderlik etmeleri; örgütün kendine özgü misyonunu ve vizyonunu verimliliğin de ötesinde tanımlayabilmeleri, savunabilmeleri ve sürdürebilmeleridir (Selznick, 1957: 17; Jung ve Choi, 2011: 47-48; Washington vd., 2008: 725). Buradaki değerler, sosyal bir varlığın içinde yer alan ideal inançlardan oluşmaktadır. Bunlar tecrübeyle elde edilirler ve ayrıca çok çeşitli etkileri zaman içerisinde ortaya çıkmaktadır. Değerlerin en önemli rolleri eylemleri motive etmeleri ve yönetmeleridir. Ayrıca değerleri ciddiye almanın bir anlamda insanları ciddiye almak olduğu da söylenebilir (Kraatz vd., 2020: 5, 22-23). Bu ciddiyetle hareket ede(bile)n yöneticiler (liderler) de, idari yönetimden kurumsal liderliğe geçiş yaparken birer "devlet adamı" haline gelmektedirler (Selznick, 1957: 4). Bu kavramlaştırma kapsamında Selznick'in (1957) orijinal ve güncel katkısının; lideri, kişiliği ve hisleriyle kurumların bilişsel ve normatif yönlerinden etkilenmeyen bir "süper birey" olarak tasvir etmesi olduğu ileri sürülebilir (Struminska-Kutra ve Askeland, 2020: 124). Aslında Selznick, bu kişilere merkezi bir rol vererek kurumların gelişmesine, uyum sağlamasına ve sürdürülmesine yardımcı olma yollarına odaklanmıştır da denilebilir (Kraatz, 2009: 59). 
Kurumsal liderlerin sadece örgütün teknik işleyişini sürdürmek için neyin gerekli olduğu konusunda değil, aynı zamanda örgütün daha geniş toplumsal yapı içindeki yeri hakkında da bir anlayış geliştirdikleri söylenebilir (Besharov ve Khurana, 2015: 62). Zira kurumlar, örgütsel amaçlara ulaşmak için gerekli olan rasyonel veya teknik gereksinimlerin ötesinde değerlerden faydalanırlar (Hansen vd., 2021: 3). Bir anlamda kurumsal liderlik, örgütsel kimlik ve örgütün daha geniş toplumsal ağlardaki rolü ve anlamı üzerinde uzun vadeli etkileri olan kararlarla ilgilidir, denilebilir (Struminska-Kutra ve Askeland, 2020: 120). Aslında bu rol, örgütlerin içinde yaşamakta oldukları kültürel çevreye karş1 yüksek derecede duyarlı olmalarından kaynaklanıyor gibi görünmektedir (Selznick, 1996: 273). Ve yine Selznick'e (1957: 60) göre böyle bir çevrede liderlerin mesuliyeti, örgütün özgün değerlerini seçmek, nihayet bunları korumak ve bu değerleri yansıtan bir sosyal yapı oluşturmaktır. Bu bakımdan değerlerin geliştirilmesi ve korunması kurumsal liderlerin birincil görevidir. $\mathrm{Bu}$ görevleri yerine getirmek adına kurumsal değerlere ve geleneklere yakından aşina olmak gerekir (Kraatz ve Moore, 2002: 125). Bu hususun bir başka yönü ise, değerlerin örgüt içindeki bütünleştirici fonksiyonu ile ilgilidir. Kraatz vd. (2020: 33) bu hususu irdelerken, iki veya daha fazla kişi “özünde” aynı değer(ler)e sahip olması halinde aralarındaki ilişkinin de muhtemelen oldukça güçlü olacağını ileri sürmektedir. Güçlü ilişki düzeyine erişen örgüt üyeleri, örgütlerinin sürdürülmesinde kişisel bir çıkar/menfaat hissedecekler ve asıl hedefleri değişse bile kurumlarını korumaya çalışacaklardır (Levitsky, 1998: 79). Hatta Scott'a (2003: 72) göre, Selznick de bir süre sonra liderlerin örgütlerinin misyonlarını savunmak, gerektiğinde, yeniden yorumlamak ve yenilemek durumunda kalabileceklerini veya kalmak durumunda olduklarını vurgulamaya başladığını ileri sürmektedir. Bu noktaya erişebilmek için örgütünün entelektüel gelişimini destekleyen ve bir öğrenme kültürü oluşturmaya çalışan kurumsal liderlerin, kurumlarının yüksek kalite standartlarının korunmasını kolaylaştırdıkları da ifade edilebilir (Garwe, 2014: 8).

Literatür tarandığında, örgütsel yaşamın maddi boyutlarını vurgulayan mevcut örgütsel perspektiflerin genellikle; politik, kültürel ve değer yüklü unsurları önemsiz gösterdikleri veya görmezden geldikleri görülmektedir (Besharov ve Khurana, 2015: 75). Mevcut çalışma işte bu noktadan hareket ederek özellikle politik, kültürel ve değer boyutlarıyla doğrudan ilişkili olarak kurumsal liderlik tarzının geleneksel ve modern dönemlerini ve yine hatta geleceğini incelemek üzere tasarlanmıştır. Bunun nedeni mevcut literatürden de anlaşılacağı üzere oldukça önem arz eden bir tasarım olarak kabul edilmesi gereken bu liderlik tarzının, geleneksel dönemden günümüze bütüncül bir bakış açısıyla çok fazla ele alınmamış ve hatta önemsenmemiş olmasıdır. Oysa son dönemde, değer odaklı çalışmaların giderek daha fazla çoğalıyor olması dikkatleri, örgütler için değer üreten ve bunları örgütlere aşılayarak kurumsallaştırmaya çabalayan liderlere yöneltmelidir. Çalışmanın bu kapsamdaki temel 
sorusu; "geleneksel dönemden modern döneme kurumsal liderlik yaklaşımının gelişimi nasıl bir seyir izlemiştir ve gelecekte olasılıkla nerede olacaktır?” olarak tasarlanmıştır.

Buradan hareketle literatür taramasına dayanılarak yapılan mevcut çalışmada, kurumsal liderliğin tarihsel gelişimine yer verilmiş ve araştırma; geleneksel dönem, modern dönem ve gelecek perspektifi temel başlıklarına ayrılarak ele alınmıştır. Genel olarak bakıldığında, kurumsal liderlik tarzının dönemler içerisinde farklı yorumlamalara tabi olduğu, çeşitli yazarlar tarafından bazı vaka çalışmalarına konu edildiği ve böylece süreçlerin ve liderlik özelliklerinin farklı boyutlarının ön plana çıkartıldığı ve yine bu kapsamda bazı önerilerin sunulduğu tespit edilmiştir. Mevcut çalışmanın verilen bu bölümlerden sonra nihayetinde sonuç bölümüyle sonlandırıldığı ifade edilebilir.

\section{TEORIK ARKA PLAN}

Bu bölümde kurumsal liderlik yaklaşımı; geleneksel dönem, geleneksel dönemden modern döneme geçiş aşaması, modern dönem ve gelecek perspektifi başlıkları altında incelenmiştir. Zira Selznick'in de (1957) vurguladığg “örgütsel tarihin” incelenmesi meselesi gibi, liderliğin de kendi tarihinin incelenmesi, en azından gelecekteki yerinin ne olacağı veya ne olması gerektiği konusunda fikir verecektir.

\subsection{Kurumsal Liderliğin Geçmişi (Geleneksel Dönem)}

Kurumsal liderlik tarzıyla ilgili öncül olarak atfedilebilecek çalışmaların oldukça kısıtlı sayıda olduğu söylenebilir. Hatta çoğu kere kavramsal olarak konu Selznick'e (1957) dayandırılsa da bundan biraz daha evvel kurumsal liderlik tarzından şu veya bu şekilde bahseden çalışmalardan söz etmek de mümkündür. Konuyla ilgili olarak yapılmış temel çalışmalar Tablo 1.'de gösterilmiştir:

Tablo 1. Kurumsal Liderlik Yaklaşımı İçin Geleneksel Dönemde Temel Eserler

\begin{tabular}{|l|l|l|l|}
\hline \multicolumn{1}{|c|}{ Çalışmanın Adı } & Yazar(lar) & \multicolumn{1}{|c|}{ Yöntem } & \multicolumn{1}{c|}{ Bulgular } \\
\hline $\begin{array}{l}\text { 1) Leadership: } \\
\text { Institutional and } \\
\text { Personal }\end{array}$ & $\begin{array}{l}\text { Sigmund } \\
\text { Neumann } \\
(1941)\end{array}$ & $\begin{array}{l}\text { Literatür } \\
\text { taraması. }\end{array}$ & Demokrasi(ler)de liderliğin önde gelen unsurları kurumsal niteliktedir. \\
\hline $\begin{array}{l}\text { 2) Leadership in } \\
\text { Administration: A } \\
\text { Sociological } \\
\text { Interpretation }\end{array}$ & $\begin{array}{l}\text { Philip } \\
\text { Selznick }\end{array}$ & Vaka analizi. & $\begin{array}{l}\text { "Devlet adamı" olarak kurumsal liderlerin birincil görevleri; değerler oluşturmak, } \\
\text { geliştirmek ve bunları örgütlerine aşılamak ve böylece örgütünü kurumsal hale } \\
\text { getirmektir. Genel olarak bakılacak olursa kurumsal liderler, diş çevreyle uyum } \\
\text { sağlamada ve örgütü kurumsallaştırmada aktif rol oynarlar. }\end{array}$ \\
\hline
\end{tabular}


Her ne kadar bu gibi yayınlar, liderliğgin değerlerle olan ilişkisine doğrudan odaklanarak kurumsal liderliği açıklamaya çalışsalar da bunlardan biraz daha evvel örgütlerde değerlerin merkezi bir role sahip olması gerektiğine ilişkin çalışmaların varlığından da söz edilebilir. Örneğin, yirminci yüzyılın başlarından ortalarına kadar Chester Barnard (1968 [1938]), Fritz J. Roethlisberger ve William J. Dixon (1939), Elton Mayo (1960 [1933]) ve George C. Homans (1950) gibi örgüt araştırmacıları, örgütün gelişimi ile değerlerin ve amacın aşılanması arasındaki içsel uyumsuzluğu sorgulamışlardır. Bu yazarlar örgütün varlığını tehdit eden herhangi bir çevresel değişiklik karşısında bir örgütün hayatta kalmasının, üyelerinin koordineli bir şekilde uyum sağlama istekliliği duymalarına ve ayrıca bu yeteneğe de sahip olmalarına bağlı olduğunu iddia etmişlerdir. Daha açık bir şekilde ifade etmek gerekirse bu durum, örgüttekilerin ortak bir amacı içselleştirme ölçülerine ve bu ortak amacı eylemleriyle gerçekleştirebilmelerine bağlıdır, denilebilir (Podolny vd., 2004: 9).

Diğer taraftan değerler, normlar ve inançlar gibi sosyal örüntüler olarak kurumların ne olduğu, eylemi ve yapıyı nasıl etkilediği hakkındaki teorileştirmeye yönelik ilk sistematik girişimlerin Max Weber ve Emile Durkheim tarafından gerçekleştirildiği de görülmektedir (Lawrance ve Shadnam, 2008: 2289). Geleneksel kurumsal liderlik modeli de bu teorik geçmiş üzerine inşa edilmiştir. Kurumsal okulun teorik temelleri, kısmen Alman sosyolog Max Weber'in çalışmalarında bulunabilir. Weber (1978), bürokrasiler gibi sosyal yapıların da "meşrulaştırıcı ilkelere" dayandığını savunmakta ve sosyal ilişkileri organize ederken uygun yolların neler olduğu konusundaki fikirleri de kabul etmektedir (Biggart ve Hamilton, 1987: 430). Yine Weber, kültürel kurallar veya sistemler kavramıyla aktöre sübjektif bir anlam yüklemiş ve eylemin sosyal olduğunu ifade etmiştir. Diğger taraftan Durkheim ise kurumları bilgi, inanç ve ahlaki otoriteye sahip sembolik sistemler olarak tanımlamış ve bunların din benzeri yaptırımlarla desteklendiğini belirtmiştir (Lawrance ve Shadnam, 2008: 2289).

Kurumsal liderlikle ilgili olarak Neumann'ın (1941) çalışması da bulunduğu dönem itibariyle özellikle göze çarpar. Bu çalışmada Neumann, zaman ve mekân açısından büyük farklılıklar gösterse de iki ana siyasi liderlik tarzının ayırt edilebileceğini vurgulamış; kurumsal ve kişisel liderlik tarzları olarak ele aldığı modellerin kabaca zit siyasi sistemlere yani demokrasi ve diktatörlüğe karşılık geldiğini söylemiştir. Ayrıca burada, bir demokraside liderliğin önde gelen unsurlarının kurumsal olduğunu ifade etmiştir (1941: 136). Devamla o, çeşitli ülkelerin devlet başkanlarından örnekler de vermiştir. Örneğin İngiltere Başbakanı'nı ele alarak sahip olduğu olağanüstü güç ve prestiji vurgulamış ve bu durumun onu kurumsal liderliğin şüphesiz en etkili prototipi haline getirdiğini belirtmiştir (1941: 136). Yine çalışmasının diğer bir örneği olan Amerikan Başkanı'nın ise renkli ve kişisel görünümü nedeniyle herhangi bir diktatörlük modelinden uzak olduğunu söylemiş ve ülkesini bu karakteriyle temsil ettiğini ifade etmiştir (1941: 137). 
Kurumsal liderliği irdelemeye kronolojik sıralamayla devam edilecek olursa, örgütlerde kurumsal teorinin en etkili versiyonlarından birisinin (aslında yaygın kanaatle en etkilisinin) Philip Selznick ve öğrencilerinin çalışmalarıyla ilişkili olduğu söylenebilir (Scott, 1987: 493). Kurumsal teorinin "babası” olarak ifade edilen Selznick, örgütlerin nasıl kurum haline geldiğiyle ve kurumsal süreçlerin örgütleri nasıl etkilediğiyle ilgilenmiştir (Greenwood vd., 2014: 1208). Selznick, Chester I. Barnard (1938, 1948) tarafından ileri sürülen fikirlerin çoğunu geliştirirken, bir “örgütü” bir "kuruma" dönüştürmek için gerekli olan çeşitli liderlik işlevlerini (örneğin misyonun tanımlanmasını, amacın kurumsal olarak somutlaşmasını, kurumların bütünlüğünün savunulmasını, iç çatışmaların düzenlenmesini vb.) kısa ve öz bir şekilde tanımlamaktadır (Terry, 1995: 520). Dikkatini küçük grupların veya çalışan kitlelerinin davranışlarına odaklamak yerine kurumsal liderliğin anlamını keşfetmek için büyük örgütlerdeki en yüksek kademelere odaklamış ve bu kademeleri özellikle ön plana çıkartmıştır (Bernstein, 1959: 197). 1957 yılında yayımlanan ve en önemli çalışmalarından biri olan "Yönetimde Liderlik: Bir Sosyolojik Değerlendirme (Leadership in Administration: A Sociological Interpretation)" adlı eseri, kurumsal liderlik sanatı üzerine bir klasik haline gelmiştir (Jung ve Choi, 2011: 47). Eserinde belirli bir kurumsal çalışan modeline merkezi rol vererek, güçlü bir kurum teorisi geliştirmiş (Kraatz, 2009: 59); “kurumsal lider/devlet adamı” olarak nitelendirdiği (1957: 154) üst düzey yöneticilere birincil görevler atfetmiştir. Bu birincil görevler; değerler ${ }^{1}$ üretmek, geliştirmek, bunları örgütlerine aşılamak, sürdürmek, korumak ve yine bunları somutlaştırmak yoluyla örgütlerinin biçimlendirilmesini sağlamak olarak ifade edilebilir (Selznick, 1957; Kraatz ve Moore, 2002: 125). Buradan hareketle Selznick'in, idarecilere değerleri seçme ve bu değerleri ifade etme sorumluluğu vermesi yönü, çalışmasının katkıları açısından oldukça önemlidir (Shinn, 1996: 36).

Aslında "örgüt” ve "kurum" arasındaki metaforik ayrımdan yola çıkarak örgütsel yaşamdaki kurumsal ve teknik alanlardaki gerilimlere odaklanmak ve bu gerilimleri uzlaştırmaya çalışmak, Selznick’in çalışmalarını ve onun liderlik anlayışını anlamanın merkezinde yer almaktadır (Jung ve Choi, 2011: 47; Besharov ve Khurana, 2015: 55-56). Ona göre kurumsallaşma aslında bir süreçtir. Örgütte zaman içerisinde meydana gelen; örgütün kendine özgü geçmişini yansıtan; içinde yer alan kişileri, bu kişilerin oluşturdukları grupları, bu kişilerin kazanılmış haklarını ve yine örgütün çevreye uyum sağlama şeklini somutlaştıran bir şeydir (1957: 16). Aslında bir örgütün "kurum" haline gelebilmesinde önemli olan, sosyal ihtiyaçların dikkate alınması ve örgütün buna uyarlanabilmesidir (1957: 5).

\footnotetext{
1 "Değer" kavramı burada "herhangi bir çıkar konusu" gibi çok genel bir anlamda kullanılmamıştır. Bundan daha ziyade ilgili örgütte kendine özgü bir amacı (veya akıbeti/sonucu/uç noktayı) belirtmek için kullanılmaktadır (Selznick, 1957: 57).
} 
İnsan benliği farklı değerleri içselleştirme (veya en azından hoş görme) yeteneğine sahiptir (Kraatz vd., 2020: 18). Buradan hareketle kurumsal bir lider olabilmek yine, yalnızca değerleri ve amacı sosyal yapıda somutlaştırmak ve başkalarının yaşamına anlam aşılamakla değil, aynı zamanda bu değerleri kendi içinde de içselleştirmek ve başkalarının davranışlarında da onların alenen temsil edildiğini görmekle ilgilidir (Besharov ve Khurana, 2015: 73; Zucker, 1977: 726). Yani sadece söylemde değil, hem kendi hem de diğer insanların eylemlerinde de bu (değer yüklü) niteliklerin tezahür ettiğini görebilmekle ilgilidir. Örgütte çalışan insanlar, sosyal etkileşim yoluyla değerler ve normlar içerisinde sosyalleştirilebiliyorlarsa (Hansen vd., 2021: 17) kurumsal liderlik perspektifi orada işliyor anlamına gelir. Ancak bunun gerçekleşmesini sağlamak ve örgütün en aşağ katmanından en tepesine kadar işleyişini görebilmek oldukça zorludur. Bu zorluğu aşmak adına kurumsal liderler seçici işe alım vasıtasıyla örgütlerinde seçkinler (elites) kitlesi oluşturabilmektedirler (1957: 14). Rol model olarak kurumların içine yerleştirilen ve kurumsal koruyucular olarak da gösterilebilecek seçkinler kitlesi; ekip kültürünü oluşturan, temel değerlere uyan ve bu değerleri geliştiren kişiler olarak tanımlanabilirler (Hansen vd., 2021: 18). Bu kişiler vasıtasıyla kurumsal liderler örgüt içerisindeki tüm kişilerin çalışma tarzlarını kendi istek ve hedefleri doğrultusunda şekillendirebilmektedirler.

Selznick' in lideri, hem kurumsallaşma etkeni hem de nihayetinde bu süreçten ortaya çıkan ve yaşayan sosyal varlığın savunucusu ve koruyucusu olan kişiler olarak tasvir edilmiştir. Bu iki kavramın onun düşüncesinde ayrılmaz bir şekilde bağlantılı olduğu söylenebilir (Kraatz, 2009: 62). Bu işlevleri yerine getirecek liderlerin, elbette çeşitli kararlar alması gerektiği ifade edilebilir. Bu noktada Selznick, rutin olarak alınan kararlarla kritik olarak alınan kararlar arasında ayrım yaparak kurumsal liderlerin ancak kritik kararlar alabilen kişiler olduğunu ifade etmiştir (1957: 24-36). Bu kritik kararların özellikle örgütün politikaları oluşturulurken de alınması gerekebilir. Selznick'in kurumsal lideri de bu anlamda hem politika oluşturmakta hem de bu yolla örgütünü inşa etmektedir (1957: 37). Ancak burada; "kaynaklar, istikrar veya itibar başarısı” örgütsel başarının ölçütü haline gelirse, o kurumun liderinin başarısız olacağını da not olarak belirtmek yerinde olacaktır (1957: 27). Bu anlayış, Selznick'in çalışmasının hâkim argümanlarından bir tanesidir. Zira Selznick görünür veya görünmez bir şekilde kurumsallaşma ve değerler üzerinden bir liderlik okuması yapmakta ve nihayet belki de başarı veya başarısızlığı, bunlarla ilişkilendirmektedir. Elbette şu hususa temas etmekte yarar vardır: Bir örgüt, kurumsallaştıkça daha fazla kaynak çekmekte, daha fazla kaynak çektikçe de istikrarlı ve yaşamını devam ettirebilen bir niteliğe sahip olmaktadır (ayrıca bkz: DiMaggio ve Powell, 1983; Meyer ve Rowan, 1977; Zucker, 1977; 1987).

Yine Selznick (1957: 135-136), örgütün temel misyonunu belirlediklerinde ve böylece görevi yerine getirebilecek sosyal bir organizma oluşturduklarında, kurumsal liderliğin verimliliğin de ötesine 
geçeceğini ifade etmektedir. Yani burada liderler "insan mühendisliğinden" (human engineering) daha da üstün bir hale gelmektedirler (1957: 136). Diğer taraftan yine ona göre, kurumsal liderler örgütlerinin misyonlarını tanımlarken iki durumu dikkate almalıdır;

(1) Kurumsal yapının içsel durumunu, yani örgüt içinde var olan çabaları, kısıtlamaları ve yetenekleri, (2) Kurumun hayatta kalabilmesini sağlayabilmek için neyin aranması veya neyin başarılması gerektiğini belirleyen dış beklentileri (1957: 67-68). Yani aslında bu tip karar ve operasyonlar için liderlerin, örgüte içsel ve dişsal olarak tam anlamıyla hâkim olmaları gerekir. Selznick'e göre başta kendisini (ve tabi örgütünü) tanımayan ve yine kısıtlamaları da göz ardı eden bir liderlik, sorumsuz bir maceracılığa veya ütopyacı duygusallığa yol açacaktır (1957: 70).

Diğer taraftan yine Selznick'e göre örgütün (kendine özgü) bir tarihi vardır. Bu tarih iç ve dış baskılara tepki veren ve tekrarlayan yanıtlardan oluşur. Bu yanıtlar belirli kalıplar şeklinde belirlendikçe sosyal bir yapı ortaya çıkar (1957: 16). Burada sosyal yapıyla aslında; rol yapısı ve hiyerarşiyle birlikte (örgütteki) iç çıkar grupları, paylaşılan inançlar ve güç bağımlılıkları da dahil olacak şekilde hem formel hem de informel unsurlar kastedilmektedir (Besharov ve Khurana, 2012: 67). Bu anlamda bir örgütün efendisi olabilmek için liderlerin, sosyal yapının her boyutuyla nasıl başa çıkabileceklerini bilmek zorunda oldukları ileri sürülebilir. Burada bireylerin ve grupların istek ve arzuları, arzulanan bir şekilde güçler dengesini kurmak için düzenlenir, teşvik ve kontrol edilir (1957: 100). Yani aslında daha geniş bir açıdan bakılacak olursa, özel değerler ve örgüte özgü yetenekler oluşturma görevi, kurumsal liderliğin en önemli işlevidir (1957: 27). Bu sayede zaman içerisinde "kurumsallaşabilen" örgütlerin özel bir karaktere bürünecekleri, kendine özgü iş yapma şekliyle (ayırt edici) bir yetkinlik (veya yetkinsizlik) kazanmışlık eğilimine girecekleri ifade edilebilir (1957: 139).

Öte yandan Selznick'in (1957) eserinde iki tür kurumsal liderliğin tanımlandığı görülmektedir. Bunlar: "sorumlu" ve "yaratıcı" kurumsal liderlerdir. Sorumlu liderlik burada; sadakatin (commitment), anlayışın (understanding) ve kararlılığın (determination) bir karışımıdır. Bu gibi liderler, -daha evvel bahsedildiği üzere- yalnızca kendi zayıflıklarını ve potansiyellerini değil, aynı zamanda işletmenin de zayıflıklarını ve potansiyellerini anlamak zorundadır (1957: 142-143). Zaten kurumsal liderlikte “devlet adamlığı” ile kastedilen şeylerin çoğu da bu kurumsal sorumlulukla ilgilidir (1957: 142). Ayrıca bu kişiler, örgütünün parçası olduğu toplulukla dengeli ilişkiler geliştirme ihtiyacının da farkında olmalıdırlar. Buna karşın, bu gereksinimlerin ne kadar gerçekçi olduğunu görmek için de çevreyi test etmeli (1957: 147) ve oportünizmle ütopyacılıktan kaçınmalıdırlar (1957: 143). Sorumlu liderin muhafazakar yapısına "değişim” ve "yeniden yapılanma” rollerini ekleyerek Selznick, yeni bir liderlik tarzına ulaşmaktadır. Bu yaratıcı rollerin aslında iki yönü vardır; amacın kurumsal olarak 
somutlaşmasını sağlamak ve stratejik ve taktiksel planlamalar yapabilmek; yani örgütün mevcut kaynaklarının ve yeteneklerinin en iyi nasıl kullanılacağını belirlemek için çevreyi analiz etmek (1957: 149). "Yaratıcı liderin" sanatı Selznick'e göre, insan ve teknolojik malzemelerin yeniden işlenerek örgütünün yeni ve kalıcı değerleri somutlaştırmasını sağlayan kurum inşa etme sanatıdır (1957: 152153). Diğer taraftan bu inşa sürecinde birçok teknik kullanılabilir. Bunların en önemlilerinden bir tanesi "mitlerin oluşturulmasıdır." Burada şunu söylemek yerinde olacaktır: Yaratıcı liderlikte önemli olan, bir mitin aktarılması değildir. Daha ziyade burada yaratıcılık; mitin gerekliliğini görmek, bunun için başarılı bir formülasyonu keşfetmek ve örgütün idealleri sürdürecek örgütsel koşulları yaratma iradesine ve anlayışına sahip olmaktır (1957: 151).

Özetle ifade edilecek olursa iki kurumsal liderlik tarzından yaratıcı liderlik, kurumu daimi akış içinde tutmayı ve onu sürekli yenilemeyi vurgulamaktadır. Bu görevler, zaman içerisinde uzmanlaşmayı da aşan bir nitelik gösteren “sorumlu liderliği”" gerektirir (Jung ve Choi, 2011: 48). Nihayet bir “yönetici, idari yönetimden kurumsal liderliğe geçiş yaparken devlet adamı haline gelir” (1957: 4).

\subsection{Geleneksel Dönem-Modern Dönem Arasındaki Boşluk: Yeni Kurumsal Yaklaşım}

Kurumsal liderlik alanında, geleneksel dönemden modern döneme geçiş arasında yeni kurumsal yaklaşımın ortaya çıkmasıyla birlikte bir boşluk oluştuğu ileri sürülebilir (Kraatz, 2009). Zira bu dönemde yapılan kurumsal araştırmalar, sektörel, alan veya küresel düzeye odaklanmış ve kurumsal liderler gibi bireysel aktörler, aktif değil pasif olarak ele alınmışlar ve birey tamamen göz ardı edilmiştir (Powell ve Colyvas, 2008; Suddaby, 2010). Ancak burada ele alınmasının nedeni bazı modern dönem kurumsal liderlik araştırmalarının (Örn: Kraatz, 2009) yeni kurumsal kuram yoluyla inşa edilmiş olmasıdır. Bundan dolayı -aslında ilk dönemleri itibariyle çok elverişli olmasa da- yeni kurumsal kuramın sonraki dönem bireysel aktörlerin eyleyenleşerek liderlik sergileme olanaklarına da değinmek yerinde olacaktır. Böylece modern dönem yaklaşımlarının nasıl bir zemin üzerine oturtulduğu sorusu kısmen de olsa cevap bulacaktır.

Kurumların kökenleri ve etkileri üzerine yapılan araştırmalardan Berger ve Luckmann'ın (1966) ufuk açıcı çalışmasına dayandırılarak başlayan (Lawrance ve Shadnam, 2008: 2290) yeni kurumsal yaklaşımın, örgütlerin rasyonel görüşlerine karşı bir tepki ve özellikle de olanakları açısından ekonomik baskılara yanıt olarak, aslında tam anlamıyla 1970'lerin sonunda ortaya çıktığı söylenebilir (bkz: Meyer ve Rowan, 1977; Zucker, 1977). Bu yaklaşımda, sembolik çevreden kaynaklanan ve diğer örgütler tarafından sosyal baskılara yanıt vermek amacıyla oluşturulmuş birçok örgütsel davranışın görüldüğünü ileri sürülmektedir (Suddaby vd., 2013: 330). Kuramın, Meyer ve Rowan (1977), DiMaggio ve Powell (1983), Meyer ve Scott (1983), Zucker (1977; 1987) gibi ilk dönem çalışmalarında, yeni kurumsal yaklaşım temsilcilerinin maksatlı hareket eden veya bilinçli aktör 
modellerini reddettikleri görülmektedir (DiMaggio ve Powell, 1991: 8). Bu yazarlar örgütsel davranışların çoğunu makro-sosyal yapılara yani kurumsal çevreden ortaya çıkan ortak kavramlara, rasyonel mitlere ve normatif beklentilere dayandırırlar (Suddaby vd., 2013: 332). Bir aktörün rolü onlar için, paylaşılan ortak özelliklerden, genelleştirilmiş beklentilerden ve davranış yorumlarından faydalanması ve böylece kurumlarını oluşturmasıdır (Barley ve Tolbert, 1997: 94).

Ancak daha sonraki eleştiriler (geniş bir değerlendirme için bkz: Suddaby, 2010), kuramda mikro temellerin oluşturulması bakımından tetikleyici bir etki yaratmıştır. $\mathrm{Bu}$ anlamda hemen hemen etraflı bir çalışmayı Powell ve Colyvas (2008) yapmışlardır. Onlara göre, kişiler de sosyal düzenin ve örgütlerin sürdürülmesinde bir girişimci olarak hizmet etmekle güçlü bir rol oynarlar. Glynn ve DeJordy (2010) biraz daha ileri giderek "liderlikle kurumsal kuramın evlendirilmesi yoluyla liderlerin, olasılıkla örgütün içinde var olduğu bağlamla açıklıkla meşgul olabileceğini” ileri sürmüşler ve bu anlamda liderlerin bu bağlamı nasıl kendi maksatları doğrultusunda kullanılabileceğine dair araştırmalar yapılabileceğini önermişlerdir. Onlar ayrıca, liderlerin kurumsal bağlamı izleyenleri için ne zaman ve nasıl tercüme ettiklerine, bu yolla kurumsal değişim gibi meseleleri nasıl gerçekleştirdiklerine dair hususları tartışmışlardır. Kraatz'ın (2009) çalışması ise, liderliği yeni kurumsal kuramın gelişmekte ve ana damarlarından olan kurumsal iş tasarımı kapsamında ele almakta ve örgütsel liderliğin bu anlamda kurumsal işlerini yedi kategori altında tanımlamaktadır. Lawrence vd. (2009) ise aynı kapsamda liderlerin, kurumsal işleri yapmak için, örgütün çekirdek değer yapılarınca desteklendiğini anlamak adına kendi dar idari rol ve teknik işlevlerini aşmaları gerektiğini ileri sürmüşlerdir. Elbette liderlerin kurumsal düzeni bu şekilde dikkate almaları, yüz yüze kalacakları koşullar hakkında kendilerine geniş bir bakış açısı da sağlayacaktır (Glynn ve DeJordy, 2010).

\subsection{Kurumsal Liderlik’te Modern Dönem}

Aktif rollere sahip olmaları yönleriyle kurumsal liderlik tarzını ele alan araştırmalarda modern dönem eserlerin başlangıcı, tarihsel süreç itibariyle 1980'li yılların ikinci yarısından itibaren başlatılabilir. Bu dönem itibariyle dikkate değer çalışmaları kısaca belirlemek gerekirse, şu şekilde tablo oluşturulabilir:

Tablo 2. Kurumsal Liderlik Yaklaşımı İçin Modern Dönemde Temel Eserler

\begin{tabular}{|l|l|l|l|}
\hline \multicolumn{1}{|c|}{ Çalışmanın Adı } & \multicolumn{1}{|c|}{ Yazar(lar) } & Yöntem & Bulgular \\
\hline $\begin{array}{l}\text { 1) Leadership and } \\
\text { Innovation }\end{array}$ & $\begin{array}{l}\text { Jameson W. Doig ve Erwin } \\
\text { C. Hargrove (Eds.) (1987) }\end{array}$ & - & $\begin{array}{l}\text { Kurumsal liderliğin iki temel bileşeni şu şekilde özetlenebilir; } \\
\text { belagat yeteneğine ve koalisyon kurma becerilerine sahip olmak. }\end{array}$ \\
\hline $\begin{array}{l}\text { 2) Unsung Heroes: Federal } \\
\text { Diffecucrats Making a }\end{array}$ & Norma M. Riccucci (1995) & - & $\begin{array}{l}\text { Siyasi beceriler, ağ becerileri ve uyarlanabilir beceriler olmak } \\
\text { üzere 3 tarzda kurumsal liderlik becerisi bulunmaktadır. }\end{array}$ \\
\hline
\end{tabular}




\begin{tabular}{|c|c|c|c|}
\hline $\begin{array}{l}\text { 3) Revisiting the Meaning of } \\
\text { Leadership }\end{array}$ & $\begin{array}{l}\text { Joel M. Podolny, Rakesh } \\
\text { Khurana, Marya Hill- } \\
\text { Popper (2004) }\end{array}$ & Literatür taraması. & $\begin{array}{l}\text { Liderler, örgütlerine amaç ve anlam aşılayabilme yeteneklerine } \\
\text { göre değerlendirilirler. Örgütlerde sadece verimliliğe } \\
\text { odaklanmak esas önemli olanların gözden kaçırılmasına sebep } \\
\text { olabilir. }\end{array}$ \\
\hline $\begin{array}{l}\text { 4) Institutional Leadership: } \\
\text { Past, Present, and Future }\end{array}$ & $\begin{array}{l}\text { Marvin Washington, } \\
\text { Kimberly B. Boal ve John } \\
\text { N. Davis (2008) }\end{array}$ & Literatür taraması. & $\begin{array}{l}\text { Kurumsal liderler kendi yaşam öykülerini örgütün ve üyelerinin } \\
\text { yaşam öyküsüyle ele alırlar. Örgüte değer aşılamak için; iç } \\
\text { tutarlılığı yönetir, dış destek mekanizmaları geliştirir ve dış } \\
\text { düşmanların üstesinden gelirler. }\end{array}$ \\
\hline $\begin{array}{l}\text { 5) The Development of } \\
\text { Public Institutions: } \\
\text { Reconsidering the Role of } \\
\text { Leadership }\end{array}$ & $\begin{array}{l}\text { Arjen Boin ve Tom } \\
\text { Christensen (2008) }\end{array}$ & Vaka çalışması. & $\begin{array}{l}\text { Kurumsal liderler örgütlerini tek başlarına değil, tasarım ilkeleri } \\
\text { olarak tanımlanabilecek bir dizi ilke yardımıyla } \\
\text { kurumsallaştırırlar. }\end{array}$ \\
\hline $\begin{array}{l}\text { 6) Leadership as Institutional } \\
\text { Work: a Bridge to the Other } \\
\text { Side }\end{array}$ & $\begin{array}{l}\text { Matthew S. Kraatz } \\
\text { (2009) }\end{array}$ & Literatür taraması. & $\begin{array}{l}\text { Kurumsal liderler, meşruiyeti ve bütünlüğü sürdürme eşzamanlı } \\
\text { ihtiyacına cevap verirler. }\end{array}$ \\
\hline $\begin{array}{l}\text { 7) Institutional Leadership } \\
\text { and Perceived Performance: } \\
\text { Evidence from the Korean } \\
\text { Minister Survey }\end{array}$ & $\begin{array}{l}\text { Kwangho Jung ve } \\
\text { Jongwon Choi (2011) }\end{array}$ & $\begin{array}{l}\text { Nicel araştırma } \\
\text { (Anket verileri } \\
\text { faktör analizi ile } \\
\text { değerlendirilmiş). }\end{array}$ & $\begin{array}{l}5 \text { tür kurumsal liderlik tarzı vardır. Bu liderlik tarzlarının her biri } \\
\text { kurumlarının performansını farklı şekilde etkileyebilmektedir. }\end{array}$ \\
\hline $\begin{array}{l}\text { 8) Leading Amidst } \\
\text { Competing Technical and } \\
\text { Institutional Demands: } \\
\text { Revisiting Selznick's } \\
\text { Conception of Leadership }\end{array}$ & $\begin{array}{l}\text { Marya L. Besharov ve } \\
\text { Rakesh Khurana (2015) }\end{array}$ & Literatür taraması. & $\begin{array}{l}\text { Birbiriyle ilişkili olduğu kadar çelişkili de olan; değerler, kültür } \\
\text { ve politika alanı ile verimlilik, rasyonalite ve idarenin teknik } \\
\text { alanında kurumsal liderler önemli görevler üstlenirler. Ayrıca } \\
\text { alanların her birinde başarı sağlamaya çalışrrlar. Değer ve amaç } \\
\text { inşa etmek kurumsal liderler için ne kadar önemliyse teknik } \\
\text { görevlerin başarılması da bir o kadar önemlidir. }\end{array}$ \\
\hline $\begin{array}{l}\text { 9) Institutional Leadership: } \\
\text { Maintaining and Developing } \\
\text { the 'Good' Organisation }\end{array}$ & Harald Askeland (2020) & Vaka analizi. & $\begin{array}{l}3 \text { Tematik çerçeve içerisinde kurumsal liderler örgütlerinin } \\
\text { anlamını ve değerlerini açık bir şekilde belirtirler, sürdürürler ve } \\
\text { geliştirirler. }\end{array}$ \\
\hline
\end{tabular}

Modern dönemin bazı vaka çalışmalarıyla yani yenilikçi kurumsal liderlik davranışlarının araştırılmasıyla başladığı söylenebilir. Örneğin Lewis (1984), kamu bürokrasilerinde girişimci aktörlerin kurumsal rolüne ilişkin bir çalışma üretmiştir. Doig ve Hargrove (1987) ise, ABD federal kurumlarındaki 14 üst düzey yöneticiden elde ettikleri verilerle kurumsal liderliğin temel bileşenlerini tanımlamaya çalışmışlardır. Çalışmalarında; kamu girişimcilerinin yeni misyonlar ve programlar belirlediklerini, yeni amaçları desteklemek için dış seçmenler oluşturduklarını ve bunları desteklediklerini ifade etmişlerdir. Öte yandan örgüt yapılarındaki değişiklikler yoluyla ayrıca iç seçmenler oluşturduklarını ve yine yeni amaçlar ve programlar uygulamak için örgütün teknik uzmanlığını artırdıklarını söylemişlerdir. Ayrıca Jung ve Choi’ye (2011: 50) göre bu yazarlar bütünsel 
bir bakış açısıyla kurumsal liderliğin iki temel bileşenini şu şekilde özetlemişlerdir: Belagat yeteneğine ve koalisyon kurma becerisine sahip olmak. Aynı şekilde Hansen vd. de (2021) kurumsal liderlikle ilgili iki temel fonksiyon tanımlamışlardır. Onlara göre liderlerin, uluslararası tutarsızlıkları yönetmeye matuf yapıları geliştirirken "kurumsal aidiyet" ve "amacın kurumsal olarak canlandırılması" şeklinde işlevler üstlenmeleri gereklidir.

Riccucci (1995) ise, ABD federal yöneticilerinde; siyasi beceriler, ă̆ becerileri ve uyarlanabilir beceriler olmak üzere üç kurumsal liderlik becerisi tanımlamıştır. İlk olarak siyasi beceriler için bu kişilerin; kilit bir siyasi atamayla güçlü bir çalışma ilişkisi geliştirmeleri, yasamada ve çıkar grubu politikalarında etkili bir yaklaşım sergilemeleri gerekmektedir. İkinci olarak ağ becerileri için; iç ve dış destek mekanizmaları geliştirmeleri ve son olarak uyarlanabilir beceriler için; mali sorunlarla ve yasama karşıtlığg gibi durumsal faktörlerle başa çıkabilmeleri gerekmektedir.

Modern dönem yaklaşımlarından Podolny vd.'nin (2004) çalışmasına bakıldığında, Selznick’in anlayışına benzer bir liderlik modeli önerdikleri görülmektedir. Selznick’te (1957) kurumsal liderlerin örgütlerine "değer aşılama" rolü bu araştırmacılarda benzer şekilde "amaç ve anlam aşılayabilme" rolüne dönüşmektedir (2004: 6). Ayrıca örgüt üyelerinin eylemlerini koşullandıran kurumsallaşmış değerlerin kaynağı da yine bu kişilerdir (2004: 1). Yazarlara göre anlamlı eylemin teknik verimliliğin ötesinde bir anlamı vardır ve bu nedenle de bu eylem örgüt üyelerin tarafından içselleştirilebilir. Bunu anlamak için örgüt içerisindeki iki bileşene odaklanmak gereklidir. Buna göre; (1) eylem, bireyin kişisel olarak değer verdiği nihai bir amacı destekliyorsa ve (2) eylem, erkek veya kadın bireyin parçası olduğu toplulukla bağlantısını doğruluyorsa anlamlı hale gelmektedir (2004: 22). Buna benzer olarak Hansen vd. de (2021: 3) kurumların, örgütsel amaçlara erişim açısından gerekli olan teknik ve rasyonel gerekliliklerin ötesinde değerleri kapsadığını ileri sürerek, aslında aynı çizgide kurumsal liderlerin daha soyut faaliyetler çerçevesinde aktif oldukları ileri sürmektedirler.

Benzer şekilde modern dönem yaklaşımcılarından Besharov ve Khurana da (2015: 82) örgütsel yaşama anlam aşılanmasının ve kurumsal bütünlüğün korunmasının kendi özleri itibariyle önemli birer amaç olduğunu ifade etmektedirler. Podolny vd.'den (2004: 29) konuya devam edilecek olursa, onlar anlamlı eylemi; (1) daha geniş bir ideale yönelik eylem ve (2) bir topluluğun diğer üyeleriyle ilişkilerinin sürdürüldüğü eylem olarak iki temel bileşeni içerecek şekilde tanımlamaktadırlar. Ayrıca yazarlara göre bir birey belirli bir eylemin temsilcisi veya yapımcısı olarak tanımlanabildiği ölçüde lider, diğer taraftan eylem ise -tek başına veya bireyin diğer eylemleriyle birlikte- başkaları için anlam yaratabildiği ölçüde liderlik eylemi olarak nitelendirilebilir (2004: 38-39). Diğer taraftan yazarlar Selznick'in, “örgütlerde verimlilikle ilgili bir saplantı halinin, en önemli olana odaklanmayı zorunlu 
olarak imkansız hale getirir” şeklindeki ifadesini destekleyerek (2004: 42) asıl olarak örgütlerde amaç ve anlama odaklanmanın önemine işaret etmektedirler.

Yine modern dönem araştırmacılarından Askeland (2020), Podolny vd.'ne (2004) benzer şekilde kurumsal liderlerin, örgütlerin anlamının ve değerlerinin ne olduğunu açık bir şekilde belirttiklerini ve bunu da ustalıkla ve dönüşümsel bir tarzda yaptıklarını ifade etmektedir (2020: 142). Liderin iyi bir örgütü sürdürme ve geliştirme çabaları yazara göre üç tematik çerçevede düzenlenebilir, bunlar; (1) iyi bir evi/yuvayı tasarlamak, (2) kamu yararının geliştirilmesine katkı sunmak ve (3) iyi uygulamalara ilişkin paylaşılan, somutlaşmış bir anlayış oluşturmak şeklindedir (2020: 144). Kurumsallaşmanın gerçekleşmesiyle örgütün zaman içerisindeki gelişimi de iç içe geçerek kendine özgü bir tarih oluşturur (2020: 140). Askeland kurumsal liderlerin bu süreçte; geçmişi, bugünü ve geleceği birbirine bağlayan anlatılar oluşturduklarını, dış değerleri-beklentileri mevcut örgütsel kimlikle şekillendirerek, sıraya koyarak ve somutlaştırarak farklı paydaş gruplarının çıkarları arasında köprü kurduklarını ifade etmektedir. Ayrıca yazar bu kişilerin, bireysel olarak değerlerin yorumlanması rolünü üstlendiklerini ve bunu da her geçen gün geliştirdiklerini belirtmektedir (2020: 153-154).

Washington ve meslektaşları da (2008: 726-727) yine benzer bir şekilde kurumsal liderleri; kendi yaşam öykülerini, örgütün ve üyelerinin yaşam öyküsüyle birlikte ele alan ve böylece vizyon oluşturma sürecini başlatan kişiler olarak tasvir etmektedirler. Vizyon belirleme ve hikaye anlatımı, bir örgütte iç tutarlılığı korumak ve istikrar sağlamak için mükemmel mekanizmalardır. Kişilerin bu becerileri sayesinde, örgütte cereyan eden eylemlerin ve olayların, hem örgütün hem de kurumsal liderin geçmişi bağlamında, tematik ve nedensel tutarlılık mercekleriyle yorumlanması mümkün hale gelecektir. Böylece liderin geçmişi ve geçmiş deneyimleri, betimleyici zihinsel modellerin geliştirilmesine önemli derecede etki etmiş olacaktır (2008: 727). Diğer taraftan kurumsal liderler gibi güçlü bireylerin, örgütün geri kalanının daha pasif bir izleyici olduğu anlatılar üretebileceğini de unutmamak gerekir (2008: 727). Yine bu araştırmacılar, kurumların tanımlanmamış bir alan (veya bir boşluk) kabul etmeyeceğini ifade ederler (2008: 729). Kurumlarında her şeyin yolunda gitmesinin yolunu, kurumsal liderin politik beceriler geliştirebilmesiyle ilişkilendirirler (2008: 731). Örgüt açısından stratejik dönüm noktası olan anların tümdengelimsel olarak tespit edilmesi neredeyse imkânsız olabilir. Ancak bu noktada kurumsal liderler, örgütün tematik tutarlılığını sürdürmeleri itibariyle, aşırı belirsizlikler karşısında başarılara ve başarısızlıklara kendi algılarını/duygularını dayatabilirler. $\mathrm{Bu}$ nedenle takipçilerine anlam oluşturmak için sıklıkla kullandıkları bir tema, "kahramanın yolculuğu” kavramıdır. Bu macerada, içerisinde bulunulan yolculuk veya mücadele ve yine muhtemel dönüş veya zafer varış yer almaktadır (2008: 726). Öte yandan kurumsal liderlerin örgütlerine değer aşılamak adına üç işlevinin olduğunu belirten yazarlar bu işlevleri; (1) hikâye 
(kolektif hikâye) anlatımları ve tematik tutarlılığın yönetimi yoluyla örgütte "iç tutarlılığı idare etmek," (2) örgütlerinin meşruiyetini artırmak için “dış destek mekanizmaları geliştirmek” ve (3) “dış düşmanların üstesinden gelmek” olarak tanımlamaktadırlar (2008: 733).

Diğer modern dönem yazarlardan Jung ve Choi (2011: 71) ise genç bir örgütte yeni vizyonlar ve misyonlar oluşturabilmenin yolunun kurumsal liderlikten geçtiğini söylemektedirler. Aynı şekilde Hansen vd. de (2021: 4) kurumsal liderlikte, liderler tarafindan desteklenen (misyon tanımlama ve amaçların somutlaştırma gibi) mekanizmaların kurumları güçlendirdiğini ifade ederler. Jung ve Choi (2011: 71) ise devamla kurumsal liderliğin rollerini; (1) örgütün misyonunu geliştirmek ve bunu aşılamak, (2) örgütün meşruiyetini artırmak için dış destek mekanizmalarını geliştirmek ve (3) kendine özgü kurumsal değerleri ve bütünlüğü korumak olarak tanımlamaktadırlar (2011: 47). Bu özellikler Selznick'te de benzer şekilde bulunmaktadır. Ancak yazarlar farklı olarak beş tür kurumsal liderlik faktörüne değinmektedirler. Bunlar; vizyoner liderlik (visionary leadership), ikna edici liderlik (persuasive leadership), esnek liderlik (resilient leadership), koalisyon ağı liderliği (coalition network leadership) ve sürdürücü liderlik (maintaining leadership) şeklinde sıralanabilir (2011: 53). Burada kurumsal liderliğin faktörlerinden vizyoner liderlik ve ikna edici liderlik tarzlarının, yazarların araştırma yaptıkları kurumlarda (yani bakanlıklarda) performans düzeyleri üzerinde, diğer kurumsal liderlik bileşenlerinden daha güçlü bir ilişki içinde olduğu tespit edilmiştir. Diğer taraftan hem esnek liderlik hem de koalisyon ağı liderliği bakanlık performansının arttırılmasında önemli bir etkiye sahiptir. Bununla birlikte, sürdürücü liderliğin bakanlık performansı üzerinde çok az etkisinin olduğu veya hiç etkisinin olmadığı görülmektedir (2011: 65-66). Bu anlamda farklı kurumsal liderlik modellerinin kurumlar üzerinde farklı etkilerinin olduğunu tespit ederek yazarlar alana önemli katkılar sağlamışlardır. Bu kişiler açısından bir bütün olarak yorumlanacak olursa kurumsal liderler; kurumları oluşturma, geliştirme ve sürdürme görevleri kapsamında çeşitli boyutlardan oluşan ortak görevler üstlenmektedirler (2011: 70).

Öte taraftan Boin ve Christensen (2008) ise kurumsal liderleri "kurum inşa edicileri" olarak nitelendirmektedirler. Ancak bu kişiler tek başlarına kurumsallaşma sürecini yüklenmemektedir. Bu anlamda onlara yardımcı olan bir takım ilkeler olmalıdır. Buradan yola çıkarak bir dizi "tasarım ilkesini" belirleyen yazarlar bu ilkeleri (2008: 12-16); (1) etkili uygulamaların peşinde olmak, deneme ve yanılma süreçlerini kolaylaştırmak, (2) normların ortaya çıkış sürecini ve örgütün kendi normu olarak kabul ettiği süreci yakından takip etmek ve bunu yönlendirmek, (3) kabul edilen normların örgüt içine yerleştirilmesi söz konusu olduğunda aktif rol oynamak ve (4) örgütü kimliğinden ödün vermeden sürekli olarak uyarlamak olarak sıralamışlardır. Kurumsal liderler onlara göre örgütlerini ancak bu ilkelerden yardım alarak dönüştürebilirler. 
Kraatz (2009: 84) ise, örgütlerin birden çok kurumsal kimliğe sahip ve birden çok kurumsal "dünya" içinde var olduğunu belirtmektedir. Yazara göre, çoğulcu ve çok amaçlı örgütler, politik olarak bölünmüş olsalar da (ve aslında bu nedenle), hâlâ kendilerinde tutarlılık, bütünleşme, uyum ve güvenilirlik görünümü yaratma ihtiyacı duyarlar (2009: 72). Bu onların aslında yeni kurumsalcılığın önemli kavramlarından birisi olarak kendini gösteren meşruiyet (bkz: Suddaby vd., 2017) arayışında olduklarını da gösterir. Kaldı ki, Kraazt da (2009) benzeri bir ifadeyle örgüt liderlerinin, yeni kurumsalcıların özellikle üzerinde durduğu meşruiyet rolüyle, Selznick'in bütüncül kurum oluşturma ve sürdürme rolünü dengelemesi gerektiğini ileri sürer (2009: 73). Bu anlamda kurumsal liderlerin örgütü hem (dâhili olarak) bütünleştirmesi, hem de (dış izleyiciler açısından) meşrulaştırması gerekmektedir. Yazara göre, liderliğin politik boyutuna, özellikle de devlet adamlığı ile "salt politika" arasındaki ince ayrıma odaklanmak oldukça önemlidir (2009: 61).

Aslında meşruiyet meselesi, kolay üstesinden gelinebilecek değilse de kurumsal liderlerin özellikle misyon ve vizyon üretme ile bu doğrultuda üstlenecekleri değer oluşturma ve bunu kurumsallaştırma rolleri itibariyle örgütle çevresi arasında bir denge oluşturabileceklerini ileri sürmek olasıdır. Kraatz (2009: 67) bu anlamda, “örgütler bütünlük ve meşruluk gerilimi arasında kurumsal halde kalır” diyerek iki liderlik tipine de atıf yapar: Çağrışımsal (connotative) ve temsil edici (denotative) liderlik. Liderlik ona göre aslında genel olarak çağrışımsal ve normatiftir. Çağrışımsal lider politik olduğu kadar bütünleştirici, amaca yönelik, özerk ve ayırt edici yönleriyle de sosyal bir bütün olan örgütünü yönetir (yazar bu durumun liderin devlet adamlığı yönü olabileceği gibi aksine sahte bir serap etkisi görünümü olabileceğini belirtmektedir). Bu kişinin kimliği, örgütün kimliğiyle derinlemesine iç içe geçmiştir. Diğer taraftan temsilci lider ise, bu niteliklerden yoksundur ve onunla kişisel bağının olmadığı bir sistemde güç kullanır (2009: 83).

Kraatz'ın kurmaya çalıştığı köprüde kurumsal çoğulculuk ile karşı karşıya olan temsilci liderler (2009: 74-81):

-Örgütün heterojen kurumsal çevresinin farklı unsurlarından kaynaklanan ve son derece önemli de olan sembolik değişimleri gerçekleştirirler ve devam ettirirler.

-Eş-atamayı (co-optation) önlemek ve birbiriyle yarış halinde olan kurumsal talepleri dengelemek için formal yapılar oluştururlar.

-Kurumsal seçmenler arasında güven kazanmak ve işbirliğini sürdürmek için değer taahhütlerinde bulunurlar.

-Kurumsal parçalanma karşısında örgütsel tutarlılık, bütünlük ve amaçlllık görünümünü yaratmaya çalışırlar. 
-Örgütsel değişimin süregelen, ortaya çıkan ve evrimsel olan süreçlerini kontrol etmeye ve örgütlerinin bütünlüğ̈̈nü sürdürmeye çalışırlar.

-Çoğulcu kurumsal çevrenin rekabet eden taleplerine cevap olarak varoluşsal, karakter tanımlayıcı seçimler yaparlar.

-Çoğulcu kurumsal bağlamın taleplerine uyum sağlama çabası içinde olarak kendileri üzerinde de çalışırlar.

Son olarak modern dönem yazarlarından Besharov ve Khurana da (2015) kurumsal liderlik bağlamında dikkatlerini öncelikle değerlerin rolüne yöneltmişlerdir. Yazarlar değerlerin korunmasının ve geliştirilmesinin liderliğin temel görevi olduğunu öne sürmüşlerdir (2015: 56). Kurumsal liderlerin, örgütlerin teknik ve kurumsal sistemler olarak ikili doğasından kaynaklanan birbiriyle ilişkili ve genellikle de çelişkili taleplerine (2015: 57) cevap vermeleri gerektiğini belirtmişlerdir. Daha önce değinildiği gibi yeni dönem bazı yazarlar da (Örn: Hansen vd., 2021) Selznick (1957) gibi bu role önem atfetmişlerdir. Besharov ve Khurana (2015) özellikle de bu tip liderlerin değerler, kültür ve politika alanı ile verimlilik, rasyonalite ve idarenin teknik alanı arasındaki kalıcı ikiliklere ve gerilimlere odaklanarak yönetecekleri önemli görevlerinin olduğunu ifade etmişlerdir (2015: 56). Bu, kurumsal liderliğin Selznick'in (1957) ifade ettiği üzere salt kurumsallaşma ve değer üretimine ilişkin fonksiyonları değil, bunların yanı sıra geleneksel birtakım fonksiyonları da üstlenmeye devam edeceklerini gösterir. Ancak dikkat edilecek olursa, örgütlerde yeni ve eski fonksiyonların yaratacağı gerilimi idare etmek de kurumsal liderler için doğal bir mesuliyet haline gelmektedir. Bu bilinçli bir aktör olarak yapılacak bir faaliyet olarak elbette eski tip kurumsalcılıktan beslenmeyi gerektirecektir.

Besharov ve Khurana (2015) ayrıca liderlerin, değerleri ve amacı tanımlarken genel olarak toplum olmak üzere örgütün içinde yer aldığı belirli toplulukların ve örgüt üyelerinin de değerlerini dikkate almaları gerektiğini ifade etmişlerdir. Ayrıca idari yöneticilerin değer kısıtlamalarını fark edip bunları kabul ettiklerinde ancak kurumsal liderliğe doğru ilerleyebileceklerini de söylerler. Dolayısıyla kurumsal liderler, salt kendiliklerinden veya kendilerini merkeze alan bir değer üretimi faaliyeti gerçekleştirmezler. Diğerlerini önceleyen, diğerlerinin değerleri ile elbette kendi değerleri uzlaştıran bir misyon ve vizyon üretimi (Selznick, 1957) temel mesuliyetleri olarak öne çıkmaktadır. Bu anlamda kurumsal liderlerin bir görevinin de kendi değerleriyle örgütün değerlerini yansitan üyelerin "kurumsal özünü” oluşturan kısmını işe koşmak ve bu üyeleri kurumlarında sosyalleştirmek olduğu söylenebilir. Böylece içinde bulundukları bu topluluk adına çaba göstermeye, tehdit edildiğinde onu savunmaya ve onun adına savunuculuk yapmaya motive olacaklarını ifade ederler (2015: 67). Bu husus, liderlik söz 
konusu olduğunda herhalde en kolay kabul edilebilecek fonksiyonlardan birini ifade eder. Kurumsal liderler de diğerleri gibi, topluluk oluşturma, bir arada tutma ve devam ettirme, topluluğu birlikte hareket etmeye sevk etme gibi temel fonksiyonları elbette üstlenirler. Ancak diğerlerinden farkı herhalde tam olarak bu noktada kendini gösterir, denilebilir. Zira kurumsal liderlerin, varlık sebebi (raison d'etre) olarak temel uğraşı, değer üretimi ve aşılanması ile kurumsallaşmasıdır. Öyleyse kurumsal liderlerin," sadece örgütlerinde değil, aynı zamanda daha genel olarak insan deneyiminde de 'gizli' olan değerleri bulmaları ve bu gizli değerlerin örgüt üyelerinde tezahür ettirilmesini sağlamaları gerekir. Bunu yapmanın yollarından bir tanesi de örgütün faaliyetlerini değerli amaçlar ve ideallere bağlayan 'sosyal olarak bütünleştirici mitler' oluşturmaktır. Liderliğin temelde yorumlayıcı ve sembolik bir eylem olduğu düşünüldüğünde, bu tip faaliyet ve eylemler de doğal bir hüviyet kazanır" (2015: 70).

\subsection{Kurumsal Liderliğin Geleceği}

Ortaya çıkan yeni gelişmeler, geçişten bugüne kendisine atfedilen roller itibariyle kurumsal liderlik yaklaşımının çok yakın gelecekte popüler araştırma konularından bir tanesi haline gelebileceğini göstermektedir. Gelecekte yapılacak çalışmaların ve bu çalışmalarda ortaya çıkartılacak bulguların beklenenden/öngörülenlerden fazlasını ortaya koyması oldukça muhtemeldir. Gelecekte yapılacak çalışmalar, geçmiş çalışmaların detaylandırılması ve buralardaki bazı soruların cevaplandırılması yönüyle gerçekleştirilecekmiş gibi de görünmektedir. Bu bölümde kurumsal liderliğin geleceğini şekillendirebilecek ve araştırmacılara yön gösterebilecek bazı konulara değinilecektir.

Öncelikle kurumsal liderler, kendilerinin ve örgütlerinin politik varlıklardan daha fazlası olduğu görüntüsünü oluştururlarken bazı yöntemler kullanmaktadırlar (Kraatz, 2009: 68). Bu yöntemlere odaklanmak oldukça önemli olabilir. Çünkü bu yöntemlerin başarısı; aslında bir anlamda kurumsal liderlerin oluşturdukları, örgütlerine aşıladıkları, sürdürdükleri ve korudukları değerlerin başarısı da demektir (karşılaştırınız: Selznick, 1957). Ancak çevresel faktörlerin, özellikle de teknolojik gelişmelerin hızlı ve sürekli gerçekleştiği göz önüne alındığında, bu yöntemlerin liderler tarafından kullanılmasının her geçen gün zorlaşacağını ileri sürmek de mümkündür. Özellikle kurumsal liderlerin, kurumlarını bu yeni gelişmelere nasıl entegre edebileceklerini tespit edecek çalışmalara ihtiyaç olduğu bir başka gerçektir. Bu araştırmalar kurumsal liderliğinin geleceğini şekillendirecek farklı bir boyutu oluşturabilir. Kısaca, kurumsal liderlerin tekno-değer odaklı yapılarla nasıl başa çıkabilecekleri, yani teknolojiyi, örgütlerinin değer üretmesi bakımından nasıl kullanacakları ve yönlendirecekleri önemli bir problematik olarak düşünülebilir.

Öte yandan sosyal aktörlerin belirli bir duruma ilişkin yorum sunabildikleri ve mevcut gruplara hitap eden eylem planlarını şekillendirebildikleri süreçler de iyi anlaşılmış değildir (Besharov ve Khurana, 
2015: 80-81). Sosyal aktörlerin işbirliği elde etmek ve örgütlerdeki çatışan eğilimleri uzlaştırmak amacıyla kullandıkları beceriler ve taktikler hakkında da yeni fikirler büyük ilgi görecektir (2015: 81). Buradan hareketle bu yeni fikirleri araştıracak çalışmaların da oldukça önemli olabileceği söylenebilir. Ayrıca çağdaş bilim, benzer liderlerin değerleri ve bütünlüğü korumalarıyla (veya en azından koruyor gibi görünmeleriyle) örgütlerinin performansını artırabileceğini de öne sürmektedir (2015: 81). Buradan hareket ederek ekonomik sonuçların da dikkate alınarak yeni çalışmaların yapılması alana oldukça büyük katkılar sağlayacaktır (2015: 82). Yani işbirliğini sağlamak-çatışmaları uzlaştırmak taktikleri ve kurumsal liderlik-performans ilişkileri bağlamında yapılacak çeşitli çalışmalar kurumsal liderliğin geleceğini şekillendirecek diğer bir boyutu oluşturabilir.

Diğer taraftan liderlerin kişisel, davranışsal ve karakteristik özelliklerinin incelenmesi yerine; örgütteki liderlik süreçlerine odaklanılması gerektiğine dair de literatürde araştırmacıların önerileri bulunmaktadır (Washington vd., 2008: 731). Bu süreçlerin detaylandırılmasıyla elde edilecek bulgular kurumsal liderlik anlayışına rehber olabilecek bir dizi ilkeyi beraberinde getirebilir. $\mathrm{Bu}$ noktada, süreçlerle de bağlantılı bir şekilde kurumsal liderlerin, "kurumsallaşmanın farklı aşamalarındaki etkileri nedir?” sorusunun cevaplanması da (Jung ve Choi, 2011: 71) kurumsal liderliğin geleceği için oldukça önemli olabilir. Özetle kurumsal liderlerin örgütteki liderlik süreçlerine ve kurumsallaşmanın farklı aşamalarındaki etkilerine odaklanmak, kurumsal liderliğin geleceğini şekillendiren diğer bir boyutu oluşturabilir.

Yine paydaşlar örgütlerin makul sonuçlar üretmelerini, varlıkları sebebiyle ekonomik gelişmeyi sağlamalarını ve sosyal refahı iyileştirmelerini beklerler. Bir örgüt, bu beklentileri karşılamadığında, o örgütün veya örgüt faaliyetlerinin meşru olup olmadığg soruları ortaya çıkmaktadır (Besharov ve Khurana, 2015: 79-80). Bu sorulara yönelik araştırmaların yapılması da kurumsal liderliğin geleceğini şekillendirebilecek başka bir boyutu oluşturabilir.

“Değerler” ekseninden devam edilecek olursa, daha yüksek analiz seviyelerini (örneğin meslekler ve devletler düzeyini) değerlendirecek kapsamlı çalışmalar yapılabilir (Kraatz vd., 2020: 43). Zira özellikle yeni kurumsal kuram, makro analizler yapması ile daha çok meşhurdur (bkz: Dimaggio ve Powell, 1983). Bu nedenle yeni dönemde Selznickçi kurumsalcılıkla yeni kurumsalcılık arasında bir bağ kurulacaksa, bu elbette kurumsal liderlik vasıtasıyla başarılabilir. Bu makro alanlarda yapılacak araştırmalarda sorulabilecek bazı sorular Kraatz vd. (2020: 51-52) tarafından şu şekilde siralanmaktadir:

-Kurumsal değerler ne zaman gerçek anlamda, dikkat çekici ve etkili olarak deneyimlenir? 
-Belli bir anda kabul edilen değerler, ileriki zamanlarda tamamen etkilerini yitirirlerse veya gözden düşerlerse örgütte neler gerçekleşebilir?

-İlk etapta hangi koşullar altında değerler gerçekleşemezler?

$\mathrm{Bu}$ ve benzeri sorular aslında farklı düzeylerde analiz yapmaya da elverişli alanlar açabilirler. Dolayısıyla kurumsal liderlik açısından bakıldığında, hemen her düzeyde farklı incelemeler yapılarak kurumsal liderlik süreçlerini açığa çıkarmak mümkün olabilir.

Diğer taraftan yine Kraatz vd. (2020: 53) belirli karar durumlarında, değerlerin değişs(k)en etkilerini inceleyen çalışmalara da ihtiyaç olacağını ve şu sorular zemininde incelemelerin de yapılabileceğini ileri sürerler:

- "Değerlerin eylemle olan bağlantısı zayıf mı güçlü mü??” ve "bu bağlantıyı güçlendirebilecek veya zayıflatabilecek güçler hakkında neler söylenebilir?",

- "Çalışanlar değerleri görmezden gelirler mi??"

- "Değerlerle motive edilen aktörler bu süreçte etik kurallarl ihlal edebilirler mi?

- "Kurumsal koşullardaki herhangi bir değişiklik kurumsal değerlere zarar verebilir mi??”

- "Kurumsal liderler böylesi durumlarda nasıl hareket etmelidir?”

Bunlar ve olasılıkla gelecek dönemde ortaya çıkabilecek daha fazla sorun ve inceleme nesnesi, kurumsal liderliğin geleceğini belirleyecekmiş gibi görünmektedir. Elbette farklı analiz düzeyleri ve birimleri kapsamında ve yine farklı analiz teknikleri ile yapılacak çalışmalar, kurumsal liderlik açısından yeni araştırma damarları açılmasına olanak sağlayabilecektir. Bugün için üzerinde uzlaşılan temel mesele, özellikle hemen her alanda "değer" (bkz: Moore, 1995) odakl1 faaliyet gösterilmesi zarureti olduğuna göre, kurumsal liderliğin giderek daha fazla ilgi çekmesi beklenmelidir.

\section{SONUÇ}

Kurumsal liderlik, farklı bir model olarak her ne kadar Selznick tarafından 1957 yılında geliştirilmiş olsa da bundan sonra çok fazla incelemeye konu edilmemiştir. Ancak yine de modele zaman içerisinde çeşitli yazarlar tarafından yeni anlamlar yüklense de araştırmacıların Selznick'in (1957) çalışmasının temel argümanlarına sadık kaldıkları ve bunları kabul ettikleri görülmüştür. Yani geleneksel dönemden uzunca bir zaman geçmiş ve birçok çalışma yapılmış olsa da kurumsal liderlik denildiğinde akla ilk gelen isim halen Selznick'tir.

Genel olarak bakıldığında modern dönem çalışmalarının geleneksel dönem çalışmalarından; kurumsal liderliği çeşitli türlere ayrılarak incelemesi, daha çok bu kişilerin kişisel özelliklerine değinilmesi, bu 
kişilerin becerilerinin çerçeve halinde sunulmaya çalışılması, yine bu kişilere yardımcı olabilecek ilkelerin bir set halinde verilmeye çalışılması ve değerlerin de örgüt performansıyla birlikte ele alınarak değerlendirilmesi gibi yönleriyle ayrıldığı görülmektedir. Yani geleneksel dönemde sade ve yüzeysel olarak değinilen kurumsal liderlik özellikleri modern dönemde çok daha fazla detaylandırılmıştır. Diğer taraftan kurumsal liderliğin geleceğini ise, örgütün hızla değişen çevresel faktörlere ve teknolojik gelişmelere nasıl uyum sağlayacağı, örgütsel süreçlere kurumsal liderlerin nasıl etki ettikleri, örgütte işbirliğini ve çatışmaları uzlaştırmayı nasıl başardıkları, kurumsal liderlik-performans ilişkisinin ne olduğu, örgütün paydaşlar nezdindeki beklentileri karşılamadığında meşru görülüpgörülmeyeceği gibi soruların cevaplandırılması şekillendirecektir. Ayrıca kurumsal değerlerle de ilgili olarak örgütsel koşulların ve süreçlerin incelenmesi, kararları etkileme olasılığını arttıran/azaltan faktörlerin belirlenmesi, diğer kurumsal unsurlarla bağlantılarının ve çeşitli sonuçlarının incelenmesi yönüyle de yapılacak çalışmalar kurumsal liderliğin geleceğini belirleyecektir.

$\mathrm{Bu}$ çalışmanın sadece literatür taramasına dayanılarak yapılması bir eksiklik olabilecekse de çalışma bütüncül bir bakışla kurumsal liderlik tarzının tarihsel olarak yorumlanmasını mümkün hale getirmiştir. Gelecekte uygulamacılar tarafından yapılacak olan çalışmalarda özellikle vaka analizleriyle kurumsal liderliğin uygulamadaki görünümlerini açığa çıkarmak mümkün olabilecektir. Değer ve kişiye özel mal ve hizmet kavramlarının, uygulamalarının giderek daha fazla önem ve hassasiyet kazandığı bugünler de kurumsal liderliğin de hem tatbiki alanda hem de kuramsal boyutta incelenme zarureti bulunmaktadır. 


\section{KAYNAKÇA}

Askeland, H. (2020). "Institutional Leadership: Maintaining and Developing the 'Good' Organisation", Understanding Values Work: Institutional Perspectives in Organizations and Leadership (Ed: Askeland H.; Espedal G.; Løvaas B. J. ve Sirris S.), Palgrave Macmillan, Cham, 139-158.

Barley, S. R. ve Tolbert, P. S. (1997). "Institutionalization and Structuration: Studying the Links between Action and Institution”, Organization Studies, 18(1), 93-117.

Barnard, C. (1938). The Functions of the Executive, MA: Harvard University Press, Cambridge.

Barnard, C. (1948). Organization and Management, MA: Harvard University Press, Cambridge.

Barnard, C. (1968). The Functions of the Executive, Harvard University Press, Cambridge.

Bass, B. M. (1985). Leadership and Performance Beyond Expectations, Free Press, New York.

Battilana, K., Leca, B. ve Boxenbaum, E. (2009). "How Actors Change Institutions: Towards a Theory of Institutional Entrepreneurship". Academy of Management Annals, 3, 65-107.

Bernstein, M. (1959). "Executives for Government: Central Issues of Federal Personnel Administration by Paul T. David and Ross Pollock; The Administrative State: An Introduction to Bureaucracy by Fritz Morstein Marx; Leadership in Administration: A Sociological Interpretation by Philip Selznick", American Political Science Review, 53(1), 195-199.

Besharov, M. L. ve Khurana, R. (2012). Leading Amidst Competing Institutional Demands: Revisiting Selznick's Conception of Leadership, Working Paper, Harvard Business School.

Besharov, M. L. ve Khurana, R. (2015). "Leading Amidst Competing Technical and Institutional Demands: Revisiting Selznick's Conception of Leadership", Institutions and Ideals: Philip Selznick's Legacy for Organizational Studies (Research in the Sociology of Organizations Vol. 44) (Ed: Kraatz M. S.), Emerald Group Publishing Limited, Bingley, 53-88.

Biggart, N. W. ve Hamilton, G. G. (1987). "An Institutional Theory of Leadership", The Journal of Applied Behavioural Science, 23(4), 429-441.

Boin, A. ve Christensen, T. (2008). "The Development of Public Institutions", Administration \& Society, 40(3), 271-297.

Burns, J. M. (1978). Leadership, Harper \& Row, New York.

DiMaggio, P. J. (1988). "Interest and agency in institutional theory", Institutional patterns and organizations, (Ed: Zucker L.), Ballinger, Cambridge, 3-22. 
DiMaggio, P. J. ve Powell, W. W. (1983). "The Iron Cage Revisited Institutional Isomorphism and Collective Rationality in Organizational Fields", American Sociological Review, 48(2), 147-160.

DiMaggio, P. J. ve Powell, W. W. (1991). "Introduction", The New Institutionalism in Organizational Analysis (Ed: Powell W. W. ve DiMaggio P. J.), The University of Chicago Press, Chicago.

Doig, J. W. ve Hargrove, E. C. (Eds.) (1987). Leadership and Innovation, The Johns Hopkins University Press, Baltimore, MD.

Garwe, E. C. (2014). “The Effect of Institutional Leadership on Quality of Higher Education Provision", Research in Higher Education Journal, 22, 1-10.

Glynn, M. A. ve DeJordy, R. (2010). "Leadership Through and Organization Behavior Lens: A Look at the Last Half-Century of Research", Handbook of Leadership Theory and Practice (Ed: Nohria N. ve Khurana R.), Harvard Business Review, Boston, 119-159.

Greenwood, R.; Hinings, C. R. ve Whetten, D. (2014). "Rethinking Institutions and Organizations", Journal of Management Studies, 51(7), 1206-1220.

Hansen, P. Ø.; Chroni S.; Skille, E. Å ve Abrahamsen, F. E. (2021). "Leading and Organising National Teams: Functions of Institutional Leadership", Sports Coaching Review, 1-22.

Homans, G. C. (1950). The Human Group, Harcourt Brace, New York.

Jung, K. ve Choi, J. (2011). "Institutional Leadership and Perceived Performance: Evidence from the Korean Minister Survey", The Korean Journal of Policy Studies, 26(2), 45-75.

Kraatz, M. S. (2009). "Leadership as Institutional Work: A Bridge to the Other Side", Institutional Work: Actors and Agency in Institutional Studies of Organizations (Ed: Lawrence T. B; Suddaby R. ve Leca B.), Cambridge University Press, Cambridge, 59-91.

Kraatz, M. S. ve Moore, J. H. (2002). "Executive Migration and Institutional Change", The Academy of Management Journal, 45(1), 120-143.

Kraatz, S. M.; Flores, R. ve Chandler, D. (2020). "The Value of Values for Institutional Analysis", Academy of Management Annals, 14(2), 1-91.

Lawrance, T. B. ve Shadnam, M. (2008). "Institutional Theory", (Ed.) Wolfgang Donsbach. The International Encyclopedia of Communication. Oxford, Blackwell Publishing, 2288-2293.

Lawrance, T. B.; Suddaby, R. ve Leca, B. (2009). "Introduction: Theorizing and Studying Institutional Work”, Institutional Work: Actors and Agency in Institutional Studies 
of Organization (Ed: Lawrance T. B.; Suddaby R. ve Leca B), Cambridge University Press, Cambridge, 1-28.

Levitsky, S. (1998). "Institutionalization and Peronism: The Concept, the Case and the Case for Unpacking the Concept", Party Politics, 4(1), 77-92.

Lewis, E. (1984). Public Entrepreneurship: Toward a Theory of Bureaucratic Political Power, Indiana University Press, Bloomington.

Mayo, E. (1960). The Human Problems of an Industrial Civilization, Viking Press, New York.

Meyer, J. W. ve Rowan, B. (1977). "Institutional Organizations: Formal Structure as Myth and Ceremony", American Journal of Sociology, 83, 340-363.

Meyer, J. W. ve Scott, W. R. (1983). Organizational Environments: Ritual and Rationality, Sage, Beverly Hills, Calif.

Moore, M. H. (1995). Creating Public Value: Strategic Management in Government, Harvard University Press, Massachusetts.

Neumann, S. (1941). "Leadership: Institutional and Personal", The Journal of Politics, 3(2), 133-153.

Podolny, J. M.; Khurana, R. ve Hill-Popper, M. (2004). "Revisiting the Meaning of Leadership", Research in Organizational Behavior, 26, 1-36.

Powell, W. W. ve Colyvas, J. A. (2008). "Microfoundations of Institutional Theory", The Sage Handbook of Organizational Institutionalism (Ed: Greenwood R.; Oliver C.; Suddaby R. ve Sahlin K.), Sage Publications, London, 276-298.

Riccucci, N. M. (1995). Unsung Heroes: Federal Execucrats Making a Difference, Georgetown University Press, Washington D.C..

Roethlisberger, F. J. ve Dixon, W. J. (1939). Management and the Worker. Harvard University Press, Cambridge.

Scott, W. R. (1987). “The Adolescence of Institutional Theory”, Administrative Science Quarterly, 32(4), 493-511.

Scott, W. R. (2003). Organizations: Rational, Natural, and Open Systems, Prentice Hall, New Jersey.

Selznick, P. (1957). Leadership in Administration: A Sociological Interpretation, Harper \& Row, New York.

Selznick, P. (1996). "Institutionalism "Old" and "New"”, Administrative Science Quarterly, 41(2), 270-277. 
Shinn, C. W. (1996). "Taking Stock of Institutional Thought: Institutions, Institutionalization, and Institutional Effects", Administrative Theory \& Praxis, 18(2), 31-41.

Silva, J. B. (2020). "Institutional Leadership-The Historical Case Study of a Religious Organisation", Understanding Values Work: Institutional Perspectives in Organizations and Leadership (Ed: Askeland H.; Espedal G.; Løvaas B. J. ve Sirris S.), Palgrave Macmillan, Cham, 81-95.

Stogdill R. M. (1948). "Personal Factors Associated with Leadership: A Survey of the Literature", The Journal of Psychology, 25, 35-71.

Struminska-Kutra, M. ve Askeland, H. (2020). "Foxes and Lions: How Institutional Leaders Keep Organisational Integrity and Introduce Change", Understanding Values Work: Institutional Perspectives in Organizations and Leadership (Ed: Askeland H.; Espedal G.; Løvaas B. J. ve Sirris S.), Palgrave Macmillan, Cham, 117-138.

Suddaby, R. (2010). "Challenges for Institutional Theory", Journal of Management Inquiry, 19(1), 14-20.

Suddaby, R.; Bitektine, A. ve Haack, P. (2017). "Legitimacy", Academy of Management Annals, 11(1), 451-478.

Suddaby, R.; Seidl D. ve K Lê J. (2013). "Strategy as Practice Meets Neo-Institutional Theory", Strategic Organization, 11(3), 329-344.

Terry, L. D. (1995). “The Leadership-Management Distinction: The Domination and Displacement of Mechanistic and Organismic Theories", The Leadership Quarterly, 6(4), 515-527.

Washington, M.; Boal, K. B. ve Davis, J. N. (2008). "Institutional Leadership: Past, Present, and Future", The Sage Handbook of Organizational Institutionalism (Ed: Greenwood R.; Oliver C.; Sahlin K. ve Suddaby R.), Sage Publications, London, 721-735.

Weber, M. (1978). Economy and Society, University of Califomia Press, Berkeley.

Zucker, L. G. (1977). "The Role of Institutionalization in Cultural Persistence”, American Sociological Review, 42, 726-743.

Zucker, L. G. (1987). "Institutional Theories of Organization", Annual Review of Sociology, 13, 443-464. 